\title{
RELATIONSHIP OF COMMUNITY UNDERSTANDING ABOUT ENVIRONMENTAL SANITATION WITH COMMUNITY ATTITUDES TOWARDS SKIN FACTORY WASTE
}

\author{
ANI MARLINA ${ }^{1}$ \& GUFRONAMIRULLAH ${ }^{2}$ \\ ${ }^{1}$ STKIPKusumanegara Jakarta, Indonesia \\ ${ }^{2}$ Muhammadiyah University of Prof. Dr. Hamka, Indonesia
}

\begin{abstract}
This study aims to determine and describe the community's understanding of environmental sanitation, know and describe the attitudes of the community towards factory waste and to find out and describe the relationship between communities understanding of environmental sanitation with community attitudes towards leather factory waste in SukaregangGarut. This research method is a correlational method, involving one dependent variable and one independent variable. The numbers of samples in this study were 30 households. The instrument used as a data collection tool took the form of a questionnaire test for people's understanding of environmental sanitation and the scale of attitudes regarding community attitudes towards leather factory waste in SukaregangGarut. The analysis used was correlational analysis using a level of confidence $=0.05$. Based on the results of the analysis of the data collected the researchers drew several conclusions, namely: Community understanding of environmental sanitation only reached 78.36, which means it is quite good, but there needs to be efforts to increase the maximum of all components of the community and local government in an effort to improve the results of community understanding about the environmental sanitation of the community. The attitude of the community towards the leather factory waste in SukaregangGarut was responded to less positively by the community in the sense that the community showed a less favorable attitude towards the leather factory waste in Sukaregang. This condition is shown by the attainment of an average public attitude towards factory waste of 77.6. Community understanding of environmental sanitation with community attitudes towards leather factory waste in Sukaregang is positively correlated with a correlation coefficient price of 0.15. This shows that there is a significant relationship between people's understanding of environmental sanitation and community attitudes towards leather factory waste in Sukaregang.

KEYWORDS: Community Understanding, Environmental Sanitation, Community Attitudes
\end{abstract}

Received: Jun 09, 2020; Accepted: Jun 29, 2020; Published: Jul 31, 2020; Paper Id.: IJMPERDJUN2020551

\section{INTRODUCTION}

Many diseases that arise because of this pollution. One example is a disease caused by the waste of the process of making the skin, in addition to causing skin diseases such as itching, sores, respiratory problems, this skin waste also causes the environment to become dirty and polluted, especially the condition of the ecosystem that is slowly not functioning (Bluyssen , 2009). As a result, the beauty of the surrounding environment is reduced and the people in the area become uncomfortable and prone to disease. Garut Regency is an area that can be regarded as a developing area. Clothing products, bags, shoes are mostly using high-tech machines, for example factories with almost $75 \%$ using mechanical power. Even factories can enter into rural areas. But in general factories were established in strategic urban areas. One of them is a leather factory in the Sukaregang area, which in the process is 
$75 \%$ using mechanical power. With the existence of this factory, the community can take advantage of the ease of obtaining the products produced without having to search long distances. However, based on field observations, it turns out that skin processing wastes are flowing into small rivers that pollute and pollute almost all rivers near people's homes in the Sukaregang area. Even though the waste is disposed of before being processed and there is a containment of waste, it still needs attention and awareness of the local community's environment. This wasted leather waste is a result of the inadequacy of factory facilities and infrastructure in each treatment to accommodate the waste. The community feels disturbed by this waste disposal because it has a negative effect on the environment, but the community cannot do anything. This is because of the lack of understanding of ways to avoid the waste that disrupts environmental sanitation as a result the waste disposal process has no other alternative except to small rivers. In this regard the authors are interested in conducting research on the relationship between the levels of community understanding of environmental sanitation with community attitudes towards leather factory waste in Sukaregang.

Through direct research into the Sukaregang community and the factory management it is hoped that they can get a meeting point from the negative impacts that unsettle the community from the presence of this waste. So get a clean environmental solution even though the leather factory continues to produce and the most basic is social relations, community psychology and factory managers remain harmonious. Jazuli (2015) suggested that the nature of the environment is determined by various factors. First, by the type and amount of each type of environmental element: air for breathing, water for drinking, household and other needs, plants and animals for food, energy, and pleasure, and land for residence and agricultural production. Humans without their environment are mere abstractions.

Environmental quality is very important because it is the basis and guidelines for achieving environmental management goals. Environmental quality is only associated with environmental problems, such as pollution, erosion and flooding. Good quality is to make people feel at home living in the environment, feeling at home is caused by people getting enough fortune, climate and other natural factors that are in accordance with the community that is also compatible with the surrounding environment (Jarrett, 2013; Jufri, 2020). Based on the description above, environmental quality can be interpreted as environmental conditions in relation to quality of life. The higher the quality of life in a particular environment, the higher the quality of the environment and vice versa. Because quality of life depends on the degree of meeting basic needs.

In a society today many industrial homes are very negative for the effectiveness of the environment, namely in the disposal of waste that is not little disposed of without any waste treatment in advance so that it can cause harm to humans not only rivers that are damaged but plants around the river it also experienced a negative impact (Inglehart, 1995). Waste can be found anywhere, in places where industrial homes or factories generally use mechanical power so that the impact on the environment around the founding of the industry, and of course, detrimental to the local community (Bayer et al., 2013). Attitude is a psychological factor found in individuals that can encourage the emergence of a person's behavior (Ajzen, 1989). This attitude can determine how individuals react to certain situations or objects that they face. According to Purwanto (2007) attitude or with what is called the English attitude is a way to react to an aphrodisiac or in other words is a tendency to react in a certain way to an aphrodisiac or the situation at hand. The concept of attitude is one of the central concepts in social psychology. Where is the follow-up of the community to carry out a response with different behaviors. Attitude, one will be able to get guidelines in applying their actions (Howarth, 2006; Fiske, 2018). 
This change is manifested in everyday life. People who understand that the effect of processing leather production is the waste that is discharged into small rivers near homes will cause environmental changes. Waste every minute or even second continues to flow into small rivers near homes. Based on this description, this study aims to identify and describe the community's understanding of environmental sanitation, find out and describe people's attitudes towards factory waste and to find out and describe the relationship between communities understanding of environmental sanitation with community attitudes towards leather factory waste in SukaregangGarut.

\section{METHODS}

The research method used in this study is a correlational research method, which is a method to find out whether there is a relationship between the levels of community understanding of environmental sanitation with community attitudes towards SukaregangGarut factory waste in the form of the correlation coefficient.

By using this method, the authors aim to provide a systematic, actual and accurate description of the facts, characteristics, and relationship of the phenomena that occur now also seeks to use whether or not there is a relationship between people's understanding of environmental sanitation with their attitude to leather factory waste in SukaregangGarut.

There are two variables in this study, namely the independent variable and the dependent variable. The independent variable is the community's understanding of environmental sanitation, while the dependent variable is the community's attitude towards leather factory waste in Sukaregang.

Community understanding of environmental sanitation shows how the community understands environmental sanitation theoretically as measured by using a questionnaire understanding test, while what is meant by community attitudes towards leather factory waste in Sukaregang is an effort to find out community attitudes towards environmental sanitation.

The design used in this study is a correlational design that can be described in the form of a chart as follows:

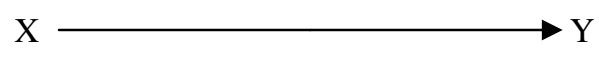

Note: $\mathrm{X}$ is an independent variable, which is people's understanding of environmental sanitation. While $\mathrm{Y}$ is the dependent variable, which is the attitude of the community towards leather factory waste in SukaregangGarut. The place of research is RW 12 SukaregangGarut, and the time of the study began in April until May 2019. The populations in this study were all Sukaregang people in RW 12 with 139 families, because in this RW there are mostly leather factories. To take a sample from that population, it is determined by the sampling technique. The numbers of people sampled in this study were 30 households (KK) out of 139 households.

\section{RESULTS}

\section{The Level of Community Understanding of Environmental Sanitation}

It is one problem that must be known clearly, considering that understanding is one of the variables in this study. Based on the data collected it is known that the highest value obtained by the community is 100 and the lowest is 43 . While the average value achieved by the community is only 78.36. This shows that the level of community understanding of environmental sanitation is quite good as expected. 


\section{The Attitude of the Community towards Leather Factory Waste in Sukaregang}

Another variable that is a problem in this study is people's attitudes towards leather factory waste in Sukaregang. The attitude of the community towards leather factory waste in Sukaregang is intended as an attitude that is able to harmonize, balance and apply the knowledge gained to leather factory waste in Sukaregang in daily life. To determine the attitude of the people of SukaregangGarut towards leather factory waste in Sukaregang, the authors analyzed the answers from the questionnaire with the following criteria: Number of statement items 30 statement items, and the largest measurement scale value $=5$, while the smallest measurement scale $=1$, so that the ideal value obtained the largest is expected to be 100 , and the smallest number is 30 , so a percentage rating criteria classification is obtained as follows: (Suharsimi, 2006).

\begin{tabular}{|c|c|c|}
\hline \multicolumn{3}{|c|}{ Table 1: Assessment criteria } \\
\hline No & Score & Measurement Criteria \\
\hline 1 & $80-100$ & Very Good \\
\hline 2 & $66-79$ & Good \\
\hline 3 & $56-65$ & Enough \\
\hline 4 & $40-55$ & Less \\
\hline 5 & $30-39$ & Failed \\
\hline
\end{tabular}

Based on the criteria it can be stated that the attitude of the Sukaregang community towards the leather factory waste in Sukaregang is good, this is indicated by the average score obtained by the community of 77.6. Individually, the attitude of the people of SukaregangGarut towards the leather factory waste in Sukaregang reached a very good criterion, with a value of 93 , and the lowest attitudes reached 63 which showed sufficient attitudes.

\section{Relationship between Community Understanding of Environmental Sanitation with Community Attitudes towards}

\section{Leather Factory Waste in Sukareganggarut}

In an effort to find out, believe in and prove whether or not there is a correlation or relationship between people's understanding of environmental sanitation and their attitude towards leather factory waste in Sukaregang, statistical tests were carried out. Some of the steps undertaken in this statistical test include: data testing (Prerequisite Test), prerequisite tests carried out including data normality test and data linearity test. The results of the two tests can be based on the following Test data normality, people understands of environmental sanitation. The results of testing the normality of community -understanding of sanitation data using the Chi-Square test, can be observed in the following table:

Table 2: Data Normality Test Results for Community Understanding Variables on Environmental Sanitation

\begin{tabular}{|c|c|c|c|}
\hline DK & ${ }^{2}$ Count & 2 List 0,95 (3) & Decision \\
\hline 3 & 4,63 & 7,81 & Normal \\
\hline
\end{tabular}

From the normality test table on the variable of community understanding of environmental sanitation above, obtained 2 Count $=4.63$ and 2D List $0.95(2)=7.81$. from these results, it turns out that 2 counts 0.95 (3) <2Lists $0.95(3)$, this shows that the data on community understanding of environmental sanitation variables come from populations that are normally distributed. Test the normality of community attitudes towards leather factory waste in Sukaregang. While the 
results of testing the data on community attitudes towards leather factory waste in Sukaregang, using the same method as the normality test for understanding data, the results are obtained as in the following tabulation.

Table 3: Test Results for Variable Normality Data Public Attitudes towards Leather Factory Waste in Sukaregang

\begin{tabular}{|c|c|c|c|}
\hline DK & ${ }^{2}$ Count & ${ }^{2}$ List 0,95 (3) & Decision \\
\hline 3 & 4,82 & 7,81 & Normal \\
\hline
\end{tabular}

From the normality test table on the variable of community understanding of environmental sanitation above, obtained 2 Count $=4.82$ and 2D List $0.95(3)=7.81$. From these results it turns out that 2 counts are $0.95(3)<2$ Lists 0.95 (3), this shows that the data on the variables of community attitudes towards leather factory waste in Sukaregang come from populations that are normally distributed.

The linearity test is intended to determine the level of alignment between the two variables, namely the level of understanding of environmental sanitation with the community's attitude towards leather factory waste in Sukaregang. To find out this, the linearity test begins with the determination of the regression linearity equation that the authors describe in the following table.

\begin{tabular}{|c|c|c|}
\hline \multicolumn{3}{|c|}{ Table 4: Regression Linearity Test Results } \\
\hline \multirow{2}{*}{ DESCRIPTION } & \multicolumn{2}{|c|}{ VALUE } \\
\hline & Understanding $(\mathbf{X})$ & Behavior(Y) \\
\hline $\begin{array}{c}\text { Regression Linearity } \\
\mathrm{D}_{\mathrm{btc}} \\
\mathrm{D}_{\mathrm{bkk}} \\
\mathrm{F}_{\mathrm{tc}} \\
\mathrm{F}_{\text {table }}\end{array}$ & $\begin{array}{r}Y=80,53+ \\
10 \\
18 \\
\\
0,42 \\
2,41\end{array}$ & $002 \mathrm{X}$ \\
\hline
\end{tabular}

From the tabulation above it appears that $\mathrm{F}_{\text {count }}=0.42<\mathrm{F} 0.05$ (Dbtc / Dbkk) $=2.41$, then the regression is called linear. This is in accordance with Nurgana's criteria (1985: 62) that if $F_{\text {count }}<F$ register linear regression is said to be linear because the results of the normality and linearity data calculation are normally distributed and linear, then the data of this study meet the requirements of correlation coefficient analysis (r). Based on the prerequisite test, the hypothesis test performed is the correlation test. Based on the results of calculations, it is known that the resulting $\mathrm{r}$ (correlation) value is 0.15 . The correlation value is a very low correlation. This means that between community understanding of environmental sanitation and community attitudes towards leather factory waste in Sukaregang has a very low correlation.

In addition, to find out the magnitude of the effect caused by the understanding of environmental sanitation on community attitudes is calculated by the coefficient of determination. The calculation results show that the coefficient of determination of the two variables is $22.5 \%$. This means that $22.5 \%$ of community attitudes towards leather factory waste in Sukaregang will be determined by the level of community understanding of environmental sanitation, while another $77.5 \%$ is determined by other influences. 


\section{DISCUSSIONS}

Based on the results of the analysis at the level of public understanding of environmental sanitation with good value, which reaches an average value of 78.36. This is due to various factors. One of them is the most important component as a good input device. This means of good input is also due to the specific knowledge of environmental sanitation obtained by all levels of society.

In addition, people's understanding of a concept is strongly influenced by several factors. These factors can come from within themselves or from the outside. Here we will point out several factors that greatly influence people's understanding of a particular concept, especially about the environment.

A characteristic of the community is one important factor whose influence is very significant in people's understanding of a particular concept. The characteristics of this society refer to the factors that exist within the community. As we know, the factors within the individual community are capital for the community who will provide motivation and stimulate the implementation of the environmental sanitation process. but it does not rule out the possibility that it will be a limiting factor.

The factors contained in the community that can improve the community's understanding of a particular concept, namely: the extent of the ability (intellectual) of the community, good interest and motivation, a positive attitude towards the environment and sanitation, regular living habits that is by neglecting obligations and deems it necessary to do a job, and are mature enough and ready to plunge continuously into environmental preservation.

The next factor that is very supportive of the community's understanding of a particular concept is derived from the available means or what is referred to as instrumental input. Factors which are supporting facilities can be one of the factors that cause an increase in public understanding of a particular concept.

Factors that cause an increase in public understanding of a particular concept that comes from adequate supporting facilities, namely: the availability of cleaning tools, a fairly wide location in the river flow, inter-community houses overlap so that hygiene maintenance such as trash can always be available each house and do not rely on each other so that the place of residence looks always clean, sufficiently mastered in protecting the environment from damage, some personal traits that benefit or support the obligations of its role as a healthy community. Furthermore, a factor that greatly influences community understanding is known as environmental input. This factor can directly or indirectly affect the role of instrument inputs that process raw inputs.

Factors included in this environmental factor are increased understanding of community knowledge, namely: In the home environment: healthy and supportive air to maintain cleanliness and the carrying capacity of good or available hygiene facilities. In the community environment: there is a large area available for river/gutter for smooth disposal of sewage.

Both of the components mentioned above have a very significant influence on the process of community understanding of environmental sanitation in a particular concept. Therefore we can consider easily the components that have been disclosed above. In addition, after seeing from the measurement of attitudes towards leather factory waste in Sukaregang, there will be known trends of people who are positive and those who are negative. However, in general the attitude of the community towards leather factory waste in Sukaregang was categorized as good. This is indicated by the 
average attitude of the community of 77.6. The poor condition of the community's attitude is certainly influenced by several factors.

The attitude of the community is formed due to the interaction experienced by the community. In an interaction of course there will be a process of influence affecting others. In a social interaction, the community will react by forming a certain attitude pattern which is certainly adjusted to the condition of the object being faced. Here several factors that have a significant influence on attitudes commonly expressed by the community will be presented here.

Every event or event that befell the community will greatly affect the attitude patterns that will be formed within the community. A reaction or response expressed by the community will be the basis for the formation of the community's attitude patterns. And of course someone will give a response or response to an event or specific event that will become an experience in itself.

It is inevitable that events experienced by humans as a result of not caring about the environment result in a very deep concern for the community. The experience experienced by a person will form a negative attitude or a positive attitude influenced by several factors. And usually, someone will have a tendency to be negative, if he has no experience at all about a certain psychological object.

Life experiences, events experienced are also very instrumental in creating one's thoughts, thus forming a paradigm that is inherent in his mind so that it does not rule out if someone will be formed by their own social environment. Good or bad attitude of a person towards a particular object depends on the social environment Barghetal., (1992), Karpinski \& Hilton, (2001) the influence of others which is considered important, the attitude of a person (the community) is greatly influenced by the people around him, for example when one community throws garbage into a ditch or a river then slowly the other community joins in. Especially people who are considered important to themselves. These people are usually family heads/adult family members, friends and other communities. Society will have a tendency to affiliate with people who are considered important, so he will have an attitude that tends to be in the same direction as him. And do not rule out the possibility, the attitude displayed aims to avoid conflict with people deemed important.

Often the attitude displayed by the community is unwittingly formed because it is solely based on a belief in that person, or it could be because of the authority of the person who is considered important. Cultural influences. This factor is no less important in shaping community attitudes. Society will have a tendency to be apathetic and even support a behavior that is contrary to the norm if he lives in a weak cultural environment. An attitude pattern that gets reinforcement from one community for that attitude, is not intended for another attitude. And here we can state that the attitude is specific according to the conditions faced or conditional (Bargh, 1989; Tiskin, 2016). Unwittingly, culture will affect people's attitudes in dealing with a problem. Only individuals who hold strong principles can escape this influence even if they are not completely free.

Educational institutions and religious institutions. The concept of morality and religious teachings are closely related to the formation of community attitudes (Duriez \& Soenens, 2006; Brammer et al., 2007). This is because moral concepts and religious teachings will give birth to a belief system. The factors above are factors that are very influential on the form factors of one's attitude. And it does not rule out the possibility of community attitudes towards leather factory waste in Sukaregang, both those with positive trends and those with negative tendencies. Influenced by factors that have been mentioned. 
Based on the description, it seems normal if there is a significant correlation or relationship between the community's understanding of environmental sanitation and the community's attitude towards leather factory waste in Sukaregang of 0.15 . In addition, it is also logical if the amount of contribution or influence caused by an understanding of environmental sanitation with community attitudes towards leather factory waste in Sukaregang is only $22.5 \%$ and another $77.5 \%$ is influenced by other factors. This is because understanding is only the smallest part of some of the effects of factors that can affect the nature and attitudes of a particular community, especially the people in SukaregangGarut.

In the end, this research gave a community understanding of environmental sanitation in the GarutSukaregang area reaching an average value of 78.36. This means that there needs to be a maximum effort from all components of the community and the local government in an effort to increase its concern both in terms of facilities and infrastructure as well as knowledge and understanding of the community's environmental sanitation. The community's attitude towards leather factory waste in Sukaregang was responded to less positively by the community in the sense that the community showed a less positive attitude towards leather factory waste. This condition is shown by the attainment of an average attitude of the community of 77.6 which indicates an unfavorable attitude.

Public understanding of environmental sanitation with community attitudes towards leather factory waste in SukaregangGarut is positively correlated with a correlation coefficient of 0.15 . This shows that there is a significant relationship between people's understanding of environmental sanitation and people's attitudes towards leather factory waste in SukaregangGarut, but the relationship is very low. The amount of contribution or effect arising from an understanding of environmental sanitation towards the formation of community attitudes towards leather factory waste in Sukaregang is shown by a coefficient of determination of $22.5 \%$. This percentage shows that $22.5 \%$ of community attitudes towards leather factory waste in Sukaregang, will be determined by their understanding of environmental sanitation, while another $77.5 \%$ will be determined by other factors. In this study the hypothesis put forward can be proven that there is a significant relationship between people's understanding of environmental sanitation and people's attitudes towards leather factory waste in SukaregangGarut.

\section{CONCLUSIONS}

Environmental sanitation is one of the important concepts to be studied in-depth, because in reality the life of the environment is an important place to interact in carrying out daily activities. If the environment is not maintained and cared for, it will also interfere with its activities. In order to provide a stronger foundation for leather factory waste in SukaregangGarut, it should be balanced with public awareness, local government, factory management in daily life. The environment will be healthy if the community and all elements in it participate in preserving and maintaining and paying attention to the positive and negative impacts. In the disposal of household waste/rubbish it should be separated between organic and non-organic waste, so that it is easily recycled.

\section{Source of Funding}

Funding sources for publishing articles use the author's personal costs.

\section{Conflict of Interest}

This article does not have the interests of any institution and does not name certain groups both in the content of the article and in terms of the location of the study. 


\section{REFERENCES}

1. Ajzen, I. (1989). Attitude structure and behavior. Attitude structure and function, 241, 274.

2. Amusan, L. M., et al. "Information on State of Challenges of Waste Management System in Nigeria Urban Housing System." International Journal of Mechanical and Production Engineering Research and Development 8.2 (2018): 75-86.

3. Bargh, J. A. (1989). Conditional automaticity: Varieties of automatic influence in social perception and cognition. Unintended thought, 3, 51-69.

4. Bargh, J. A., Chaiken, S., Govender, R., \&Pratto, F. (1992). The generality of the automatic attitude activation effect.Journal of personality and social psychology, 62(6), 893.

5. Bayer, P., Rybach, L., Blum, P., \&Brauchler, R. (2013). Review on life cycle environmental effects of geothermal power generation. Renewable and Sustainable Energy Reviews, 26, 446-463.

6. Bluyssen, P. M. (2009). The indoor environment handbook: how to make buildings healthy and comfortable. Routledge.

7. Brammer, S., Williams, G., \&Zinkin, J. (2007).Religion and attitudes to corporate social responsibility in a large cross-country sample.Journal of business ethics, 71(3), 229-243.

8. Duriez, B., \& Soenens, B. (2006). Religiosity, moral attitudes and moral competence: A critical investigation of the religiosity-morality relation. International Journal of Behavioral Development, 30(1), 76-83.

9. Fiske, S. T. (2018). Social beings: Core motives in social psychology. John Wiley \& Sons.

10. Howarth, C. (2006). How social representations of attitudes have informed attitude theories: the consensual and the reified. Theory \& Psychology, 16(5), 691-714.

11. Inglehart, R. (1995). Public support for environmental protection: Objective problems and subjective values in 43 societies. PS: Political Science \& Politics, 28(1), 57-72.

12. Jarrett, H. (2013). Environmental quality in a growing economy: essays from the sixth RFF forum. Routledge.

13. Jazuli, A. (2015). DinamikaHukumLingkunganHidupdanSumberDayaAlamdalamRangka Pembangunan Berkelanjutan. JurnalRechtsVinding: Media PembinaanHukum Nasional, 4(2), 181-197.

14. Jufri, R. F. (2020). The Effect of Environmental Factors on Microbial Growth. Journal La Lifesci, 1(1), 12-17.

15. Karpinski, A., \& Hilton, J. L. (2001). Attitudes and the implicit association test. Journal of personality and social psychology, 81(5), 774 .

16. Ketaren, S. Otniel, et al. "Environmental health aspect in health emergency management (a case study: SinabungVulcanous Eruption)." Int. J. Appl. Nat. Sci. 5 (2016): 47-56.

17. Lalitha, A., and R. Neela Rani."Development of Multimedia Module on Domestic Water Sanitation Management." International Journal of Agricultural Science and Research (IJASR), ISSN (P) (2018): 2250-0057.

18. Purwanto, N. (2007). Psikologipendidikanremaja. Bandung: Rosdakarya.

19. Suharsimi, A. (2006). Prosedurpenelitiansuatupendekatanpraktik. Jakarta: RinekaCipta. 
20. Suganya, K., R. Velusamy, and S. Thiyageshwari. "Augmenting the Liquid Waste Management Skills of Rural Shg Women of Madurai District Through Eco-Wash Literacy." International Journal of Agricultural Science and Research (IJASR) 7.4 (2017): 359-362.

21. Tiskin, D. (2016). Conditional attitude ascription. Epistemology \& philosophy of science, 50(4), 74-93. 